\title{
Cytogenetic description of Bunocephalus doriae Boulenger, 1902 (Siluriformes: Aspredinidae) from the Paraná River (Misiones, Argentina)
}

\author{
Alberto Sérgio Fenocchio ${ }^{1}$ and Ana Cláudia Swarça ${ }^{2}$
}

In this work, Bunocephalus doriae was cytogenetically analyzed. A karyotype with a diploid number of $2 \mathrm{n}=50$ comprising $6 \mathrm{~m}$, $10 \mathrm{sm}, 6 \mathrm{st}$, and 28a $(\mathrm{FN}=72)$ chromosomes was observed. The occurrence of an asymmetric karyotype with a large number of acrocentric chromosomes distinguishes this species from others the Order Siluriformes. An exclusive character observed is the first pair of subtelocentric as the largest chromosome pair of the complement. NORs detected using AgNO3 were located in the terminal regions, on the short arm of a subtelocentric chromosome pair (pair 11), in a secondary constriction. C-banding revealed heterochromatic centromeric regions on several chromosomes of the complement after C-banding. This is the first cytogenetic description of this species and the first cytogenetic report on a member of the family Aspredinidae.

No presente trabalho, Bunocephalus doriae. foi analisado citogeneticamente. O número diploide encontrado foi $2 \mathrm{n}=50$ compreendendo $6 \mathrm{~m}, 10 \mathrm{sm}, 6 \mathrm{st}$, and $28 \mathrm{a}(\mathrm{NF}=72)$ cromossomos. A ocorrência de um cariótipo assimétrico com um grande número de cromossomos acrocêntricos distingue esta espécie das demais pertencentes à Ordem Siluriformes e foi observada como característica exclusiva a presença do primeiro par subtelocêntrico, sendo o maior do complemento. As NORs detectadas pelo AgNO3 foram observadas na região terminal do braço curto de um par cromossômico subtelocêntrico (par 11), em uma constrição secundária. A heterocromatina, após o bandamento $\mathrm{C}$, foi visualizada em regiões centroméricas de vários cromossomos do complemento. Esta é a primeira descrição citogenética desta espécie e a primeira descrição de um membro da família Aspredinidae.

Key words: AgNORs, C-banding, Chromosomes.

\section{Introduction}

Fishes of the family Aspredinidae are commonly known as "banjo catfishes" due to their overall body shape, depressed head and slender caudal peduncle, which somewhat resembles the musical instrument (Myers, 1960). Their skin is completely keratinized and covered with tubercles and periodically the entire outer layer of skin is shed just like that of amphibians and reptiles (Friel, 1989). This family comprises 13 genera and 39 species (Eschmeyer \& Fong, 2011). Bunocephalus species are found in the Magdalena, Orinoco, Amazon, Paraguay-Paraná, and São Francisco Rivers. Within the family, this genus is the most widely distributed. It is also the only aspredinid genus found west of the Andes range, in the Atrato, San Juan, and Patia rivers (Ferraris, 2007). The species Bunocephalus doriae (Boulenger, 1902) is endemic to Paraguay-Paraná and Uruguay basins (Ferraris, 2007). This paper aims to cytogenetically characterize Bunocephalus doriae for the first time using Giemsa, AgNOR, and C-banding.

\section{Material and Methods}

Four specimens (three females and one male) of Bunocephalus doriae from Paraná River (Posadas-Argentina) were studied cytogenetically. The specimens were deposited in the collection of the Laboratory of Fish Cytogenetics and Environmental Monitoring of the Universidad Nacional de Misiones-UNaM, voucher numbers: 115, 116, 117 and 118. Mitotic chromosome preparations were obtained according to Bertollo et al. (1978). NOR silver staining was performed using the method of Howell \& Black (1980). C-banding

${ }^{1}$ Universidad Nacional de Misiones, Depto. de Genética, Félix de Azara 1552, 3300, Posadas, Misiones, Argentina. afenocch@fceqyn.unam.edu.ar

${ }^{2}$ Universidade Estadual de Londrina, CCB, Depto. de Histologia, C.P. 6001, 86051-970, Londrina, PR, Brazil. swarca@uel.br 
analyses were performed using the method described by Sumner (1972). Chromosome morphology was determined on the basis of arm ratio (AR) as proposed by Guerra (1986) and chromosomes were classified as metacentric (m), submetacentric (sm), subtelocentric (st) and acrocentric (a). NF (chromosome arm number) was determined considering each $\mathrm{m} / \mathrm{sm} / \mathrm{st}$ chromosome as having two arms and each acrocentric chromosome as consisting of one single arm.

\section{Results}

Bunocephalus doriae is the first species of the Aspredinidae family cytogenetically described. The modal diploid number determined for the individuals of Bunocephalus doriae examined was 50 chromosomes (Fig. 1a), with no chromosomal differences detected between males and females. Within the order Siluriformes, the only species
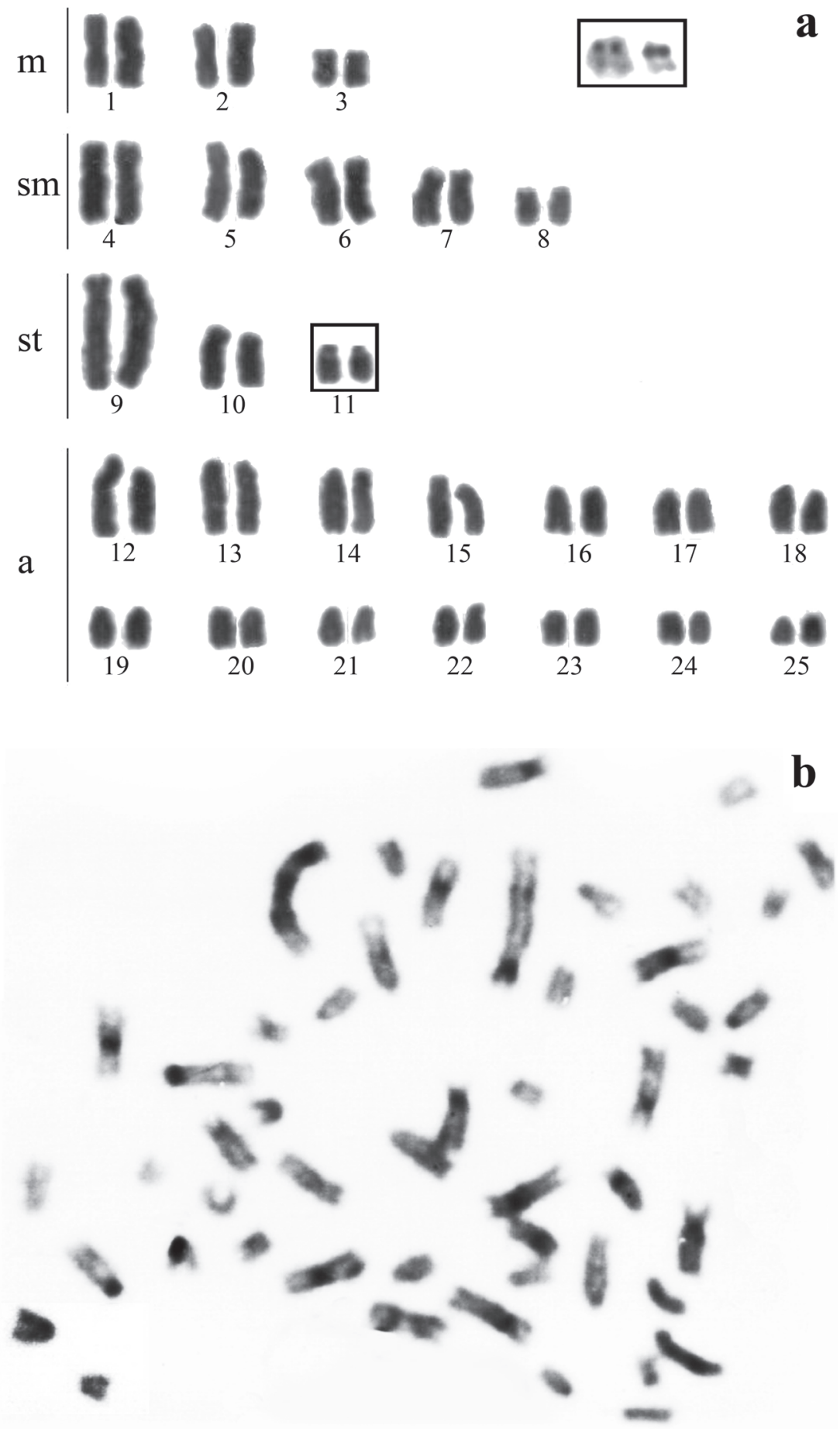

Fig. 1. Karyotypes with conventional Giemsa staining (a) and C-banding (b). Boxes display chromosomes bearing AgNORs. 
with $2 \mathrm{n}=50$ chromosomes studied so far belong to the Pimelodidae family (i.e. Pinirampus pirinampu, Calophysus macropterus, Luciopimelodus pati) (Swarça et al., 1999; Vasconcelos \& Martins-Santos, 2000; Sanchez, 2006). Oliveira $\&$ Gosztonyi (2000) reported that karyotypes of $2 n=56$ have been reported in thirteen genera of Siluriformes, suggesting that this could be the basal chromosome number for the order. However, considering the few cytogenetic data available for some groups, generalizations should be carefully revised (Swarça et al., 2007).

The chromosome formulae established consisted of $6 \mathrm{~m}$, $10 \mathrm{sm}, 6 \mathrm{st}$, and $28 \mathrm{a}$ and the fundamental number (FN) was 72 (Fig. 1a). A very interesting and exclusive characteristic observed was the presence of the first pair of subtelocentrics as the largest chromosome pair of the complement. The presence of an asymmetric karyotype with a large number of acrocentric chromosomes in Bunocephalus doriae sets this species apart from all other species belonging to the Order Siluriformes, characterized by a large number of biarmed chromosomes and therefore, high values of $\mathrm{FN}$ as one of its main chromosomal features (Swarça et al., 2007).

Silver staining allowed the detection of NORs on terminal regions of the short arm of a subtelocentric chromosome pair (pair 11) in a secondary constriction (Fig. 1a). These results (e.g. NORs on terminal regions of the short arm) were also observed in species of the sister groups Auchenipteridae (Fenocchio \& Bertollo, 1992; Ravedutti \& Júlio Jr, 2001; Lui et al., 2009) and Doradidae (Fenocchio et al., 1993, Eler et al., 2007, Milhomem et al., 2008). Likewise, other species such as Pinirampus pirinampu, Calophysus macropterus, and Luciopimelodus pati (Swarça et al., 1999; Vasconcelos \& Martins-Santos, 2000, Sanchez, 2006), which share the same diploid chromosome number with Bunocephalus doriae, also exhibited NORs on the short arms of a subtelocentric chromosome pair.

Heterochromatin was visualized in centromeric regions of several chromosomes of the complement (Fig. 1b) after Cbanding. The $\mathrm{C}-$ banding pattern was similar to the ones reported for Doradidae (Milhomem et al., 2008) and Auchenipteridae (Lui et al., 2009).

\section{Discussion}

The anatomical distinctiveness of aspredinids creates a wide gap between it and other Neotropical catfish families. Also, the relationships among families have always been obscure, and there have been few explicit proposals about its possible closest relatives (Pinna, 1996), however, Diogo et al. (2001) pointed out five derived characters that are exclusively present in the aspredinid catfishes, and constitute Aspredinidae autapomorphies. Some of these characters when compared with other aspredinid and other catfishes constitute a support for hypothesis about autoapormophies and phylogenetic relationships among species of this family. The $\mathrm{C}-$ banding pattern was similar to the ones reported for Doradidae (Milhomem et al., 2008) and Auchenipteridae (Lui et al., 2009).
The latter hypothesis was confirmed by a recent molecular phylogenetic analysis substantiating that aspredinids are the sister group to a clade containing the Neotropical Auchenipteridae and Doradidae (Sullivan et al., 2006). Currently, there are no cytogenetic data available to corroborate this hypothesis until more studies are carried out on these groups.

\section{Acknowledgements}

The authors are grateful to Larissa Bettin Pires and Marceléia Rubert for assistance in preparation of the photos.

\section{Literature cited}

Bertollo, L. A. C., C. Takahashi \& O. Moreira-Filho. 1978. Cytotaxonomic considerations on Hoplias lacerdae (Pisces, Erythrinidae). Brazilian Journal of Genetics, 1: 103-120.

Diogo, R., M. Chardon and P. Vandewalle. 2001. Osteology and myology of the cephalic region and pectoral girdle of Bunocephalus knerii, and a discussion on the phylogenetic relationships of the Aspredinidae (Teleostei: Siluriformes). Netherlands Journal of Zoology 51: 457-481.

Eler, E. S., J. A. Dergam, P. C. Vênere, L. C. Paiva, G. A. Miranda \& A. A. Oliveira. 2007. The karyotypes of the thorny catfishes Wertheimeria maculate Steindachner, 1877 and Hassar wilderi Kindle, 1895 (Siluriformes: Doradidae) and their relevance in doradids chromosomal evolution. Genetica, 130:99-103.

Eschmeyer, W. N. \& J. D. Fong. 2011. Species of Fishes by family/ subfamily. On-line version dated 14 Jul 2011. http:// research.calacademy.org/research/ichthyology/catalog/ SpeciesByFamily.asp

Fenocchio, A. S. \& L. A. C. Bertollo. 1992. Karyotype similarities among Pimelodidae (Pisces, Siluriformes) from the Brazilian Amazon region, Cytobios, 69:41-46.

Fenocchio, A. S., L. C. Jorge, P. C. Venere \& L. A. C. Bertollo. 1993. Karyotypic characterization and nucleolus organizer regions in three species of Doradidae (Pisces, Siluriformes). Revista Brasileira Genetica, 4:1097-1101.

Ferraris Jr., C. J. 2007. Checklist of catfishes, recent and fossil (Osteichthyes: Siluriformes), and catalogue of siluriform primary types. Zootaxa, 1418: 1-628.

Friel, J. P. 1989. Epidermal keratinization and molting in the banjo catfishes (Siluriformes: Aspredinidae). Abstracts of the 1989 Annual Meeting of the American Society of Ichthyologists and Herpetologists at San Francisco State University, p. 89.

Friel, J. P. 2008. Pseudobunocephalus, a new genus of banjo catfish with the description of a new species from the Orinoco River system of Colombia and Venezuela (Siluriformes: Aspredinidae). Neotropical Ichthyology, 6: 293-300.

Friel, J. P. 2009. Asprenidae. Banjo Catfishes. Version 02 March 2009 (under construction). http://tolweb.org/Aspredinidae/15208/ 2009.03.02 in The Tree of Life Web Project, http://tolweb.org/.

Guerra, M. 1986. Reviewing the chromosome nomenclature of Levan et al. Brazilian Journal of Genetics, 4: 741-746.

Howell, W. M. \& D. A. Black. 1980. Controlled silver staining of nucleolus organizer regions with a protective colloidal developer: a one step method. Experientia, 36: 1014-1015.

Milhomem, S. S. R., A. C. P. Souza, A. L. Nascimento, J. R. Carvalho Jr, E. Feldberg, J. C. Pieczarka \& C. Y. Nagamachi. 2008. 
Cytogenetic studies in fishes of the genera Hassar, Platydoras and Opsodoras (Doradidae, Siluriformes) from Jarí and Xingú Rivers, Brazil. Genetics and Molecular Biology, 31: 256-260.

Myers, G. S. 1960. The genera and ecological geography of the South American banjo catfishes, family Aspredinidae. Stanford Ichthyological Bulletin, 7: 132-139.

Oliveira, C. \& A. E. Gosztonyi. 2000. A cytogenetic study of Diplomystes mesembrinus (Teleostei, Siluriformes, Diplomystidae) with a discussion of chromosome evolution in Siluriforms. Caryologia, 53: 31-37.

Sánchez, S. 2006. Estudios citogenéticos em peces de la família Pimelodidae (Pisces, Siluriformes) de la cuenca del rio Paraná, Argentina. Unpublished Ph.D, Dissertation. Universidad Nacional de Córdoba, Argentina.

Sullivan, J. P., J. G. Lundberg \& M. Hardman. 2006. A phylogenetic analysis of the major groups of catfishes (Teleostei: Siluriformes) using rag1 and rag2 nuclear gene sequences. Molecular Phylogenetics and Evolution, 41: 636-662.

Sumner, A. T. 1972. A simple technique for demonstrating centromeric heterochromatin. Experimental Cell Research, 75: 304-306.

Swarça, A. C., L. Giuliano-Caetano \& A. L. Dias. 1999. Cytogenetic characterization through chromosomic banding of Pinirampus pirinampu (Pisces, Pimelodidae) from the Tibagi river basin PR/Brazil. Caryologia, 52: 31-35.

Swarça, A. C., A. S. Fenocchio \& A. L. Dias. 2007. An update cytogenetic review for species of the families Pseudopimelodidae, Pimelodidae and Heptapteridae (Pisces, Siluriformes). Suggestion of a cytotaxonomical classification. Caryologia, 60: 338-348.

Vasconcelos, C. \& I. C. Martins-Santos. 2000. Chromosome polymorphism in species of the Pimelodidae family (Pisces, Siluriformes). Hereditas, 132: 103-109.

Submitted September 10, 2010 Accepted July 11, 2011 Published June 29, 2012 